\title{
Transcriptomics of Bronchoalveolar Lavage Cells Identifies New Molecular Endotypes of Sarcoidosis
}

Milica Vukmirovic ${ }^{\star 1,11}$, Xiting Yan*1,2, Kevin F. Gibson ${ }^{3}$, Mridu Gulati ${ }^{1}$, Jonas C. Schupp ${ }^{1}$, Giuseppe Deluliis ${ }^{1}$, Taylor S. Adams ${ }^{1}$, Buqu Huํ․ Antun Mihaljinec ${ }^{1}$, Tony Woolard $^{1}$, Heather Lynn ${ }^{1,8}$, Nkiruka Emeagwali ${ }^{1}$, Erica L. Herzog ${ }^{1}$, Edward S. Chen ${ }^{4}$, Alison Morris ${ }^{3}$, Joseph K. Leader ${ }^{3}$, Yingze Zhang ${ }^{3}$, Joe G. N. Garcia ${ }^{8}$, Lisa A. Maier $^{5}$, Ron Colman 9 , Wonder P. Drake ${ }^{6}$, Michael Becich ${ }^{3}$, Harrison Hochheiser ${ }^{3}$, Steven R. Wisniewski ${ }^{3}$, Panayiotis V. Benos ${ }^{3}$, David R. Moller ${ }^{4}$, Antje Prasse ${ }^{10}$, Laura L. Koth ${ }^{7}$, Naftali Kaminski ${ }^{1}$

${ }^{1}$ Section of Pulmonary, Critical Care and Sleep Medicine, Department of Internal Medicine, Yale University School of Medicine, New Haven, CT/US

2 Department of Biostatistics, Yale School of Public Health, New Haven, CT/US

${ }^{3}$ University of Pittsburgh, School of Medicine, Pittsburgh, PA/US

${ }^{4}$ Johns Hopkins University, Baltimore, MD/US

${ }^{5}$ National Jewish Health - Denver, CO/US,

${ }^{6}$ Vanderbilt University, Nashville, TN/US

${ }^{7}$ University of California San Francisco, San Francisco, CA/US

${ }^{8}$ University of Arizona Health Sciences, Tucson, AZ/US

${ }^{9}$ University of Pennsylvania School of Medicine, PA/US

${ }^{10}$ Hannover Medical School, Hannover (MHH), Germany

${ }^{11}$ Department of Medicine, Division of Respirology, McMaster University, Hamilton, ON, Canada 
On behalf of the GRADS Investigators

* Equally contributing authors

Address correspondence: naftali.kaminski@yale.edu

300 Cedar Street, PO Box 208057, New Haven, CT 06520-8057

Phone (203) 737-4612 / Fax (203) 785-6094

\section{Sources of support}

This work is supported by NIH grants: U01 HL112707, U01 HL112694, U01 HL112695, U01 HL112696, U01 HL112702, U01 HL112708, U01 HL112711, U01 HL112712, UL1

RR029882, UL1 RR025780, R01 HL110883, R01 HL114587, CTSI U54 grant 9 UL1 TR000005, CDC NMVB 5U24 OH009077, CTSA UL1 TR002535, R21 LM012884 


\begin{abstract}
Sarcoidosis is a multisystem granulomatous disease of unknown origin with a variable and often unpredictable course and pattern of organ involvement. In this study we sought to identify specific bronchoalveolar lavage (BAL) cell gene expression patterns indicative of distinct disease phenotypic traits.

RNA sequencing by lon Torrent Proton was performed on BAL cells obtained from 215 well characterized patients with pulmonary sarcoidosis enrolled in the multicenter Genomic Research in Alpha-1 Antitrypsin Deficiency and Sarcoidosis (GRADS) study. Weighted Gene Co-expression Network Analysis (WGCNA) and non-parametric statistics were used to analyze genome wide $\mathrm{BAL}$ transcriptome. Validation of results was performed using a microarray expression data set of an independent sarcoidosis cohort (Freiburg, Germany $(n=50)$ ).

Our supervised analysis found associations between distinct transcriptional programs and major pulmonary phenotypic manifestations of sarcoidosis including; TH1 and TH17 pathways associated with hilar lymphadenopathy; TGFB1 and MTOR signaling with parenchymal involvement, and IL7 and IL2 with airway involvement. Our unsupervised analysis revealed gene modules that uncovered four potential sarcoidosis endotypes including hilar lymphadenopathy with increased acute $\mathrm{T}$ cell immune response; extraocular organ involvement with PI3K activation pathways; chronic and multiorgan disease with increased immune response pathways; and multiorgan with increased IL-1 and IL-18 immune and inflammatory responses. We validated the occurrence of these endotypes using gene expression, pulmonary function tests and cell
\end{abstract}


differentials from Freiburg. Taken together our results identify BAL gene expression programs that characterize major pulmonary sarcoidosis phenotypes and suggest the presence of distinct disease molecular endotypes.

Word count: 242 (abstract up to 290 words), 3391 (manuscript up to 3000 words)

Keywords: Sarcoidosis; Pulmonary; Bronchoalveolar lavage; RNA sequencing; Novel molecular endotypes; WGCNA; PFT; Disease heterogeneity.

Take home message: Genome wide BAL transcriptomics identified novel gene expression profiles associated with distinct phenotypic traits in sarcoidosis and is suggestive of the presence of novel molecular and clinical sarcoidosis endotypes that could help with further understanding of this heterogenous disease. 
medRxiv preprint doi: https://doi.org/10.1101/2020.07.24.20161448; this version posted July 27, 2020. The copyright holder for this preprint (which was not certified by peer review) is the author/funder, who has granted medRxiv a license to display the preprint in perpetuity. It is made available under a CC-BY-NC-ND 4.0 International license .

\section{INTRODUCTION}

Sarcoidosis is a granulomatous disease of unknown etiology that can affect almost every organ, but affects the lungs in majority of the cases $(>90 \%)$. The patterns of organ involvement and disease course are often unpredictable, but a substantial number of patients suffer either a relapsing or progressive course with mortality estimated at $12 \%$ in advanced cases [1-3]. The etiology of sarcoidosis is still unknown. Despite significance advances in understanding the contribution of genetic predisposition, immune aberrations and the presence of microbial antigens in patients with sarcoidosis, little is known about the genetic networks and environmental factors that determine the phenotype in sarcoidosis. Similarly, treatment is still based on immunosuppression, with corticosteroids serving as first line, and then use of 'steroid sparing' agents with limited evidence of long term benefit $[4,5]$. Genetics and genomics studies on sarcoidosis have focused on identifying DNA variants or gene signatures associated with sarcoidosis [6-12]. Genomewide association studies (GWAS) have found associations between MHC region and HLA-DRB1 variants and disease severity and sarcoidosis risk. Most previous whole transcriptome studies focused on identifying gene signatures that distinguish sarcoidosis from control; progressive from non-progressive disease; or from other granulomatous diseases such as tuberculosis [6-13]. While highly informative, they were mostly focused on the peripheral blood, limited in size, heterogeneity of disease manifestations and depth of phenotyping.

In this study, we performed a genome-wide transcriptome analysis of bronchoalveolar lavage (BAL) samples collected from a large cohort of well characterized sarcoidosis patients recruited by the Genomic Research in Alpha-1 Antitrypsin Deficiency 
medRxiv preprint doi: https://doi.org/10.1101/2020.07.24.20161448; this version posted July 27, 2020. The copyright holder for this preprint (which was not certified by peer review) is the author/funder, who has granted medRxiv a license to display the preprint in perpetuity. It is made available under a CC-BY-NC-ND 4.0 International license.

and Sarcoidosis (GRADS) study [14]. We conducted both supervised and unsupervised analysis on the measured gene expression profiles of these BAL samples to identify gene signatures that are associated with the heterogeneity in the clinical and phenotypic manifestations of sarcoidosis. The results suggest the presence of novel molecular and clinical endotypes of sarcoidosis. 
medRxiv preprint doi: https://doi.org/10.1101/2020.07.24.20161448; this version posted July 27, 2020. The copyright holder for this preprint

(which was not certified by peer review) is the author/funder, who has granted medRxiv a license to display the preprint in perpetuity.

It is made available under a CC-BY-NC-ND 4.0 International license .

\section{METHODS}

\section{GRADS Patient Population}

BAL samples were available from subjects enrolled in the GRADS study as previously described [14]. After informed consent and recruitment screening (Supplementary Figure S1) patients were grouped into predefined phenotypic groups based on a modified organ assessment instrument developed by the ACCESS study [15] and described by us in detail [14]. The collected phenotypic information according to the GRADS study protocol include physiological parameters, high-resolution computed tomography (HRCT), BAL, and detailed questionnaires assessing dyspnea, fatigue and quality of life, current and past medical information, occupational, and environmental exposures among others. All recruitment and consenting procedures were compliant with current HIPAA regulations and approved by the local institutional review board (IRB) [14].

\section{Freiburg Validation Cohort}

BAL gene expression data from Affymetrix Human Gene 1.0 ST Arrays were available from 50 individuals with Sarcoidosis recruited independently in Freiburg, Germany. The consents were collected following institutional IRB protocols.

\section{Sample Preparation and Transcriptomic Analysis}

Total RNA was extracted as previously described [16] (Supplement Material). For GRADS samples cDNA libraries were generated, amplified and sequenced on the lon Proton $^{\mathrm{TM}}$ System for Next-Generation Sequencing to obtain sequencing depth of $\sim 30$ million single-end reads/sample with an average read length of 150bps (Supplementary 
medRxiv preprint doi: https://doi.org/10.1101/2020.07.24.20161448; this version posted July 27, 2020. The copyright holder for this preprint (which was not certified by peer review) is the author/funder, who has granted medRxiv a license to display the preprint in perpetuity. It is made available under a CC-BY-NC-ND 4.0 International license .

Table S1). Gene expression in Freiburg samples was quantified using the Affymetrix Human Gene 1.0 ST Arrays (Supplementary Material).

\section{Statistical Analysis}

The supervised analysis identified gene signatures associated with predefined phenotypical traits using non-parametric tests (Supplementary Material). Unless otherwise stated in the text we used the false discovery rate (FDR) to control for multiple testing error. The unsupervised analysis used the weighted gene co-expression network analysis (WGCNA)[17]. Genes from chosen WGCNA modules $(p<0.05)$ were used to cluster the patients into subgroups using K-means clustering (Supplementary Material). Chi-square test and Wilcoxon rank sum test were used to assess the significance for categorical and continuous patient characteristics $(p<0.05)$, respectively, amongst the clusters for chosen gene modules (Supplementary Material). The MetaCore ${ }^{\mathrm{TM}}$ of GeneGO, Inc. was applied to identify significant enriched pathways (FDR<0.05) for each gene module identified by the unsupervised analysis. The data are publicly available on the GEO database (http://www.ncbi.nlm.nih.gov/geo/) under the accession number GSE109516. All analysis codes and results are available on github page (https://yalep2med.github.io/SARC_BAL). 


\section{RESULTS}

\section{Patient Cohorts}

GRADS cohort: Based on RNA quality and quantity as well as the quality of RNASeq data of BAL samples, we included 209 BAL samples from 8 predefined clinical phenotype groups [14]: 25 stage I, 34 stage II-III treated, 42 stage II-III untreated, 19 stage IV treated, 12 stage IV untreated, 14 acute sarcoidosis, 40 remitting and 23 subjects with multiorgan involvement (Table S1). 53.6\% were female and $23.4 \%$ were black (Table 1a). For the Freiburg cohort, 50 BAL samples were available, $100 \%$ of patient were white, 32 were male and 18 were female. The clinical information collected included demographics and 12 clinical phenotypic traits overlapping with the GRADS protocol (Table 1b).

\section{Gene expression patterns associated with hilar lymphadenopathy, parenchymal or}

\section{airway involvement}

We assessed the association of gene expression of 209 BAL samples with 24 predefined clinical traits including Scadding staging, PFTs, CT parameters, age, gender, BAL cell counts and the eight phenotypic groups. This analysis revealed distinct genes associated with most traits $(F D R<0.05)$ as well as overlapping genes (Figure 2a, Supplementary tables).

Increased Scadding stage, was significantly associated with increased expression in 166 genes and decreased expression in 29 genes (Figure 2a). Of these genes, many were also significantly associated with CT traits such as hilar lymphadenopathy (17 genes), and reticular abnormalities (83 genes). In the presence of both progressive 
medRxiv preprint doi: https://doi.org/10.1101/2020.07.24.20161448; this version posted July 27, 2020. The copyright holder for this preprint (which was not certified by peer review) is the author/funder, who has granted medRxiv a license to display the preprint in perpetuity. It is made available under a CC-BY-NC-ND 4.0 International license .

Scadding staging and more reticular abnormality, increased genes include PLA2G7, ID1, LGMN, CCL2 and decreased genes include PDLIM1 and AOC3. SLC40A1 was increased with progressive Scadding staging, more reticular abnormality and more hilar lymphadenopathy. These genes are known to be involved in fibrosis and chronic obstructive lung disease [18-20]. Genes increased with progressive Scadding staging were enriched for IL1, IL8 and IL6 pathways (Figure 2A), previously associated with inflammatory bowel disease [21] and lung fibrosis [18]. Interestingly, many of these genes are also increased with changes in clinical traits not included in the definition of Scadding stage, such as increased bronchial wall thickening (68 genes ; TREM2, CHIT1, LGMN) and decreased FEV1\% and FVC\% (47 and 6 genes; IDI1 and INSIG1), previously reported in sarcoidosis $[22,23]$.

Among the CT phenotypic traits, reticular abnormality, hilar lymphadenopathy, and bronchial wall thickening were significantly associated with large numbers of genes $(757$, 266 and 487 respectively, Figure 2a). Genes increased in the presence of hilar lymphadenopathy were enriched for Th1 and Th17, IFN-gamma, and NFAT signaling (Figure 2b). These include genes CD28, STAT1, CXCR3, CCR4 known to drive T cell receptor and Interferon signaling as well as the $\mathrm{TH} 1 / \mathrm{TH} 2$ balance and previously reported in sarcoidosis [24, 25]. Genes increased with more severe bronchial wall thickening (Figure 2b) are enriched for aberrant IL-2 and IL-7 pathways including MRC2, SLC40A1, F2R, IL7, PTPN7, ADORA2A, SPRY2, PLA2G7, PTGS1. Reticular abnormalities on CT scan were positively correlated with many known fibrosis associated genes such as TGFBR1, COL3A1, TLR3, ID1, TCF4, IGFBP6, PLA2G7, FADS1, ARGHAP12, and MMP10 [26-29]. Interestingly, ID1, HMGC1, SEPP1 were also inversely correlated with 
medRxiv preprint doi: https://doi.org/10.1101/2020.07.24.20161448; this version posted July 27, 2020. The copyright holder for this preprint (which was not certified by peer review) is the author/funder, who has granted medRxiv a license to display the preprint in perpetuity. It is made available under a CC-BY-NC-ND 4.0 International license .

DLCO\% and FVC\%, potentially reflecting the shared biology underlying physiological restriction, loss of diffusion capacity and reticular abnormalities. Pathway analysis of positively correlated genes with reticular abnormality revealed an enrichment for MTOR (Cytochrome C, SC5D, HIF1A, PPAR alpha), and cell cycle (CDC25C, CHK2, CDK1) signaling that was also seen in genes increased with progressive Scadding staging (Figure 2b).

Taken together, our results suggest that different transcriptional programs affect the three major phenotypic manifestations of pulmonary involvement in sarcoidosis with TH1, TH17 associated with hilar lymphadenopathy, TGFB1 and MTOR signaling for parenchymal involvement and IL7 and IL2 for airway involvement.

Genes associated with race are also associated with hilar lymphadenopathy, parenchymal or airway involvement

308 genes were associated with race (188 increased in white and 120 in black; Figure 2A). SLC22A16, NME4, PWP2, ASRGL1 and SCARB1 were the top increased genes in blacks while CD300C, LAMA1, RNF135, ST14 were the top genes increased in whites (Figure 2a). Expression of SLC22A16 and PWP2 were previously shown to be race dependent in cancer patients [30]. Aberrant lipid trafficking, CoA biosynthesis and arachidonic acid production were enriched in the genes higher in black while no enriched pathway was found for the genes higher in white. Genes increased in blacks had a significant overlap with genes increased with progressive Scadding stage (MYOZ1, SQRDL, FAM213A), decreased PFTs (TCEA3, FAM213A, MYO1E, CYP51A1, SQLE) being consistent with findings from previous studies on the importance of race in the 
medRxiv preprint doi: https://doi.org/10.1101/2020.07.24.20161448; this version posted July 27, 2020. The copyright holder for this preprint (which was not certified by peer review) is the author/funder, who has granted medRxiv a license to display the preprint in perpetuity. It is made available under a CC-BY-NC-ND 4.0 International license .

disease severity [31]. Genes increased with reduced lung function (DLCO\%, FVC\%, FEV1\%), increase in reticular abnormality and in black subjects were associated with SCAP/SREBP transcriptional control of cholesterol and fatty acid biosynthesis (Figure $2 b)$, potentially reflecting race specific pathways of injury.

Genes increasing with higher lymphocyte fraction in BAL reveal shared transcriptional programs related to hilar lymphadenopathy and bronchial wall thickening

Disease activity is known to be associated with changes in BAL cell composition [32]. While total BAL cell count was associated with only a small number of genes, lymphocytes and macrophages fractions in BAL were associated with the largest number of associated genes (2,435 and 1,284 respectively, Figure 2a, Supplement Tables). Among the top genes (Spearman's rho $>0.3$, FDR $<0.05$ ) positively correlated with increased lymphocyte count were known markers of T lymphocyte subpopulations such as CD2, CD3, CD6, CD5, CD96 and CD247 [33-36]. Amongst other positively correlated genes were: markers of lymphocyte activation (ITK, LCK, CD28, CTLA4, IL2RB), the granzymes GZMA, GZMB and GZMH, ETS1, the chemokines and their receptors (CCL5, CXCL9, CCR4, CXCR3,4,6) and cytokines such as IFNG, IL6, IL26, IL32 and their receptors (IL2RB,G, IL12RB2, IL15RA, IL18RA, IL21RA), and inflammatory regulators (JAK3, NFATC and NKB2). Genes significantly correlated with lymphocyte count significantly overlapped with those genes associated with bronchial wall thickening, hilar lymphadenopathy, Scadding but not with genes associated with reticular abnormality, PFT and demographics (Figure 2A). Among the genes positively correlated with both 
medRxiv preprint doi: https://doi.org/10.1101/2020.07.24.20161448; this version posted July 27, 2020. The copyright holder for this preprint (which was not certified by peer review) is the author/funder, who has granted medRxiv a license to display the preprint in perpetuity. It is made available under a CC-BY-NC-ND 4.0 International license .

lymphocyte count and bronchial thickening were CCR5, CCR6, CD84, CD28, IL12RB, IL18R, IL21R and IFNG, potentially reflecting activation of CD4+ T lymphocytes, T:B lymphocytes interactions, Th1 inflammatory response and susceptibility to sarcoidosis [37-40]. The increased lymphocyte count associated genes that overlapped with increased hilar lymphadenopathy were LY9, GNAO1, IFNG, F2R, CCR 4/5/8), CD6, CD5 and KIF21B [41]. Genes associated with higher lymphocyte fractions were associated with numerous immune $\mathrm{T}$ cell responses (TH1/TH17, INF-gamma, OX40L/OX40), follicular T-Helper cell dysfunction, T-cell co-signaling receptors, and SLE genetic marker genes (Figure 2b, Supplement Tables).

WGCNA gene modules associate significantly with PFTs, CT imaging features and

\section{BAL cell differentials}

The WGCNA analysis identified 48 gene modules and evaluated the correlation of their eigen genes with PFTs, CT imaging features (mediastinal and hilar lymphadenopathy, traction bronchiectasis, micronodule, ground glass, reticular abnormality) and BAL cell differentials (Supplementary Figure E3). Among the 48 modules, 5 modules (module 1, 4, 18, 33 and 47) were significantly correlated ( $p$ value $<0.05)$ with multiple clinical traits and we focused on them for further investigation (Figure 3a).

Module 4 (1,626 genes) was positively correlated with most CT imaging features, BAL cell differentials and Scadding staging suggesting a plausible link between BAL gene expression, increased Scadding stage, increased lymphocytes and eosinophils differentials, and negatively correlated with macrophage differential and FEV1/FVC ratio (Figure 3a). Module 1 had the largest number of genes $(7,258)$ was negatively correlated 
medRxiv preprint doi: https://doi.org/10.1101/2020.07.24.20161448; this version posted July 27, 2020. The copyright holder for this preprint (which was not certified by peer review) is the author/funder, who has granted medRxiv a license to display the preprint in perpetuity. It is made available under a CC-BY-NC-ND 4.0 International license .

with all PFT\% predicted, and positively correlated with the presence of mediastinal lymphadenopathy and reticular abnormality. No correlation was found for BAL cell differentials or the total BAL cell counts suggesting the existence of large number of gene signatures associated with lung function regardless of the BAL cell differentials. In addition, module 18 (99 genes) was negatively correlated with FEV1\% predicted, FVC\% predicted and FEV1/FVC ratio as well as macrophage differential. Module 33 (51 genes) was positively correlated with the presence of mediastinal and hilar lymphadenopathy, micronodule, traction bronchiectasis, lymphocyte and eosinophil cell differentials (Figure 3a). Module 47 contained 21 genes that correlated with sex or with absolute PFT but not \% predicted PFT, reflecting the effect on sex on PFT.

\section{Four gene modules are suggestive of novel molecular endotypes of sarcoidosis}

To define novel disease endotypes we performed K-means clustering analysis using genes from each of the WGCNA modules to identify clusters of sarcoidosis patients with distinct clinical traits (Figure 4).

Clustering based on the genes in Module 4 identified clusters of patients who differed clinically with one group having significantly more hilar and mediastinal lymphadenopathy, larger lymph nodes, increased Scadding stage, less remitting phenotype and more lymphocytes in BAL (Figure 4c, cluster C) than the others. These patients had a history of increased exposure to woodfire smoke and had more skin and kidney involvement. Increased $\mathrm{T}$ cell immune response and decreased signal transduction via cAMP and PKA was observed in this cluster of patients suggesting that 
medRxiv preprint doi: https://doi.org/10.1101/2020.07.24.20161448; this version posted July 27, 2020. The copyright holder for this preprint (which was not certified by peer review) is the author/funder, who has granted medRxiv a license to display the preprint in perpetuity. It is made available under a CC-BY-NC-ND 4.0 International license .

these patients have an acute lymphocytic inflammation (Figure 4c, Supplementary Table E3).

Clustering patients based on genes in module 1 revealed clusters of patients who differed clinically and environmentally with one group having significantly more mediastinal lymphadenopathy and reticular abnormality in the lung, less multi-organ phenotype (affected eyes), more environment effects and with more subjects living in Arizona and Tennessee. Up-regulation of apoptotic, immune response and development pathways related to PI3K activation was observed in the same cluster of patients (Figure 4a, cluster A, Supplementary Table E3).

Clustering patients based on genes in module 33 revealed clusters of patients who differed clinically with one group, cluster $\mathrm{C}$, having significantly more lymphocytes in BAL and more lymph organ involvement, more exposure to sand, less fatigue and did less work in the house than patients in cluster B. Patients in cluster $\mathrm{C}$ were more chronic and had higher multiorgan involvement than cluster A (Figure 4d, Supplementary Table E3).

Clustering patients based on genes in module 18 identified clusters of patients who differed clinically and environmentally with one distinguished group (Figure 4e, cluster C) having significantly more patients from Connecticut, New Jersey, New York, Pennsylvania and Tennessee, more lung, joint and kidney involvement, increased urinary calcium and were exposed to more wood coal before diagnosis. However, these patients have less mediastinal lymphadenopathy and micronodules than patients in cluster B (Figure 4e, Supplementary Table E3). Increased IL-1 and IL-18 immune and inflammatory responses were observed in cluster $\mathrm{C}$ (Figure 3b). 
medRxiv preprint doi: https://doi.org/10.1101/2020.07.24.20161448; this version posted July 27, 2020. The copyright holder for this preprint (which was not certified by peer review) is the author/funder, who has granted medRxiv a license to display the preprint in perpetuity. It is made available under a CC-BY-NC-ND 4.0 International license .

\section{Novel sarcoidosis endotypes validated using an independent cohort}

To validate the endotypes we discovered, we used the genome wide BAL transcriptome data from an independent cohort of sarcoidosis patients (Freiburg cohort). The Freiburg patients were clustered using genes from each of the 4 novel modules and gender module independently (Figure 4). Available Scadding stage, age, gender, BAL cell differential and PFTs were compared between the two extreme patient clusters defined by each module in both GRADS and Freiburg cohorts (Table 2). The comparison showed that the endotype of gender including PFTs (module 47) was fully validated. For the endotype of hilar lymphadenopathy and acute lymphocytic inflammation (module 4), the association with macrophages, lymphocytes, neutrophils, PFTs and age were validated. Module 18, a chronic sarcoidosis endotype, and Module 33, a multiorgan involvement, were validated for age, Scadding, gender, PFTs, macrophages and lymphocytes counts. Module 1, an extraocular organ involvement and PI3K activation was validated for all clinical traits besides FVC\% and FEV1\%.

We also found overlap in genes significantly associated with FVC\% predicted and FEV1\% predicted in both cohorts with 16 and 39 genes for $\mathrm{FVC} \%$ predicted and $\mathrm{FEV} 1 \%$ predicted, respectively (chi-square $p$ value $=2.22 \mathrm{e}-16$ and $7.41 \mathrm{e}-12$ ). Amongst the top negatively correlated genes with FVC\% in both cohorts were: COL1A2, IGFBP6, MAT2A, AQP9, GJA1 and EPDR1 suggestive of involvement of IGF family signaling pathways. The 39 genes highly negatively correlated with FEV1\% predicted included: CYP51A1, FADS1, COL1A1, HSPA7, LDLR, and NFKB1 suggestive of involvement of NF-kB related pathways. 
medRxiv preprint doi: https://doi.org/10.1101/2020.07.24.20161448; this version posted July 27, 2020. The copyright holder for this preprint (which was not certified by peer review) is the author/funder, who has granted medRxiv a license to display the preprint in perpetuity. It is made available under a CC-BY-NC-ND 4.0 International license .

\section{DISCUSSION}

Our study based on genome-wide transcriptome analysis of 209 BAL samples represents the first and the largest effort to examine the BAL transcriptome in sarcoidosis with pulmonary involvement. Using both, supervised and unsupervised analysis, our study revealed specific gene profiles correlated with activity and severity of disease including immune, inflammatory and profibrotic mediators. Most importantly, our study identified four new groups of sarcoidosis patients with specific molecular, clinical and environmental characteristics.

The unsupervised analysis identified 4 gene modules that were strongly correlated with CT imaging features of pulmonary involvement, Scadding stage, and BAL cell differentials. These modules further identified groups of patients with 1) hilar lymphadenopathy and acute lymphocytic inflammation, 2) extraocular organ involvement and $\mathrm{PI} 3 \mathrm{~K}$ activation, 3) chronic sarcoidosis, 4) multiorgan involvement with increased immune response (Figures 3 and 4). Identification of BAL gene modules represents a robust and novel molecular approach to address clinical heterogeneity of sarcoidosis patients initially classified into 8 clinical phenotypes in GRADS study [14]. BAL gene modules had the strongest correlation with multiple clinical features suggestive of pulmonary involvement which might be the top factor to consider for further patient phenotyping, as previously suggested [42]. Gender response gene module clearly separated female from male patients based on 15 out of 21 gene expression, suggesting on accuracy and sensitivity of our method (Figure 3 and 4 and Supplement table E3). Previously, unsupervised clustering approaches used solely clinical patient 
medRxiv preprint doi: https://doi.org/10.1101/2020.07.24.20161448; this version posted July 27, 2020. The copyright holder for this preprint (which was not certified by peer review) is the author/funder, who has granted medRxiv a license to display the preprint in perpetuity. It is made available under a CC-BY-NC-ND 4.0 International license .

characteristics to successfully subgroup sarcoidosis patients based on organ involvement (lung, abdominal, heart, muscle and extrapulmonary) or to modulate sarcoidosis based on personal and environmental factors $[43,44]$. Our study is the first to combine clinical and environmental factors with BAL transcriptome data to phenotype sarcoidosis with pulmonary involvement.

Supervised analysis identified numerous divergent and convergent gene expression patterns associated with hilar lymphadenopathy, parenchymal or airway involvement in sarcoidosis (Figure 2). Our results suggest that different transcriptional programs affect the three major phenotypic manifestations of pulmonary involvement in sarcoidosis with $\mathrm{TH} 1$ and $\mathrm{TH} 17$ associated with hilar lymphadenopathy, TGFB1 and MTOR signaling for parenchymal involvement, and IL7 and IL2 for airway involvement. These responses were amongst identified pathways and also known to be involved in sarcoidosis pathogenesis $[6,8,45,46]$. An increase in reticular abnormality observed in chest radiology of sarcoidosis patients was associated with increased molecular signaling in BAL such as: growth factor, apoptosis/survival, mTORC1 and immune CD28 signaling (Figure 2). The activation of these signaling pathways is suggestive of granuloma formation and presence of fibrosis in sarcoid lungs [47-49]. Genes associated with race (black) were also associated with hilar lymphadenopathy, aberrant lipids pathways, parenchymal or airway involvement in sarcoidosis. However, our data do not provide more evidence to demonstrate if this difference is race specific or directly related to the presence of sarcoidosis, as described previously [50] or due to differences in disease severity and manifestations. Genes positively correlated with increased lymphocyte 
medRxiv preprint doi: https://doi.org/10.1101/2020.07.24.20161448; this version posted July 27, 2020. The copyright holder for this preprint (which was not certified by peer review) is the author/funder, who has granted medRxiv a license to display the preprint in perpetuity. It is made available under a CC-BY-NC-ND 4.0 International license .

fraction in BAL reveal shared transcriptional programs related to hilar lymphadenopathy and bronchial wall thickening. Genes positively correlated with increased macrophage fraction in BAL are associated with increased cell differentiation, and development pathways such as PI3K/AKT, MAPK, and BMP7 signaling suggesting indirectly that these BAL macrophages were in contact with inflammatory sites and granuloma core in lungs (Supplement Material) [51, 52]. Genes positively correlated with decreased eosinophil fraction in BAL were associated with decreased airway thickness and could reflect the level of lung inflammation, as well as on severity and progression of sarcoidosis (Supplement Material).

Our study has several limitations including samples size, heterogeneity of clinical features and confounding effect of BAL cell differentials. Although our study collected a relatively large sample size for transcriptomics analysis, the unpredictable course and presentation of sarcoidosis that leads to heterogeneity of clinical features limited us in identifying more than 4 distinct endotypes in the GRADS sarcoidosis cohort $[14,53,54]$. Another limitation of our study is the impact of the BAL cell differentials on the gene expression data for gene modules 4 (hilar lymphadenopathy and acute lymphocytic inflammation) and 33 (multiorgan involvement with increased immune response) but not for modules related to gender, chronic sarcoidosis and extraocular organ involvement. We were also not able to provide a complete transcriptomics link to treatment [55] and race effects [56]. 
In summary, our study identified gene profiles associated with major phenotypic manifestations of pulmonary involvement in sarcoidosis, as well as identified 4 novel endotypes. Future analyses of the GRADS cohort of individuals with sarcoidosis will focus on understanding the link between BAL and blood gene expression and their relationship with phenotypes of sarcoidosis.

\section{Acknowledgments}

We thank all patients who participate in the GRADS study for contributing samples.

Authors' Contributions: NK, LLK, DM, KFJ, WD conceived and designed the experiments; KFG, MG, SMN, MB, HH, EH, ESC, AM, JKL, JGNG, SRW, LAM, DRM, KP, WPD conducted patient phenotyping, classification, supervised sample and data collection; MV, TA, TW and JD performed the RNA sequencing experiments; JS and AP collected and generated the microarray data of the Freiburg cohort for validation; $\mathrm{XY}, \mathrm{MV}$, NK, BH, AM, YZ, NE, PVB, JS, AP analyzed the data; NK, XY, MV and LLK supervised the analytic plan; MV, XY and NK wrote the manuscript with input from all other authors. All authors have read and approved the manuscript. 


\section{REFERENCES}

1. Statement on sarcoidosis. Joint Statement of the American Thoracic Society (ATS), the European Respiratory Society (ERS) and the World Association of Sarcoidosis and Other Granulomatous Disorders (WASOG) adopted by the ATS Board of Directors and by the ERS Executive Committee, February 1999. Am J Respir Crit Care Med 1999: 160(2): 736-755.

2. Iannuzzi MC, Rybicki BA, Teirstein AS. Sarcoidosis. N Engl J Med 2007: 357(21): 2153-2165.

3. Swigris JJ, Olson AL, Huie TJ, Fernandez-Perez ER, Solomon J, Sprunger D, Brown KK. Sarcoidosis-related mortality in the United States from 1988 to 2007. Am J Respir Crit Care Med 2011: 183(11): 1524-1530.

4. Baughman RP, Costabel U, du Bois RM. Treatment of sarcoidosis. Clin Chest Med 2008: 29(3): 533-548, ix-x.

5. Morgenthau AS, lannuzzi MC. Recent advances in sarcoidosis. Chest: 139(1): 174-182.

6. Rosenbaum JT, Pasadhika S, Crouser ED, Choi D, Harrington CA, Lewis JA, Austin CR, Diebel TN, Vance EE, Braziel RM, Smith JR, Planck SR. Hypothesis: sarcoidosis is a STAT1-mediated disease. Clin Immunol 2009: 132(2): 174-183.

7. Lockstone HE, Sanderson S, Kulakova N, Baban D, Leonard A, Kok WL, McGowan S, McMichael AJ, Ho LP. Gene set analysis of lung samples provides insight into pathogenesis of progressive, fibrotic pulmonary sarcoidosis. Am J Respir Crit Care Med 2010: 181(12): 1367-1375. 
medRxiv preprint doi: https://doi.org/10.1101/2020.07.24.20161448; this version posted July 27, 2020. The copyright holder for this preprint (which was not certified by peer review) is the author/funder, who has granted medRxiv a license to display the preprint in perpetuity. It is made available under a CC-BY-NC-ND 4.0 International license .

8. Gharib SA, Malur A, Huizar I, Barna BP, Kavuru MS, Schnapp LM, Thomassen MJ. Sarcoidosis activates diverse transcriptional programs in bronchoalveolar lavage cells. Respir Res 2016: 17(1): 93.

9. Zhou T, Zhang W, Sweiss NJ, Chen ES, Moller DR, Knox KS, Ma SF, Wade MS, Noth I, Machado RF, Garcia JG. Peripheral blood gene expression as a novel genomic biomarker in complicated sarcoidosis. PLoS One 2012: 7(9): e44818.

10. Maertzdorf J, Weiner J, 3rd, Mollenkopf HJ, Network TB, Bauer T, Prasse A, Muller-Quernheim J, Kaufmann SH. Common patterns and disease-related signatures in tuberculosis and sarcoidosis. Proc Natl Acad Sci U S A 2012: 109(20): 7853-7858.

11. Koth LL, Solberg OD, Peng JC, Bhakta NR, Nguyen CP, Woodruff PG.

Sarcoidosis blood transcriptome reflects lung inflammation and overlaps with tuberculosis. Am J Respir Crit Care Med 2011: 184(10): 1153-1163.

12. Su R, Li MM, Bhakta NR, Solberg OD, Darnell EP, Ramstein J, Garudadri S, Ho M, Woodruff PG, Koth LL. Longitudinal analysis of sarcoidosis blood transcriptomic signatures and disease outcomes. Eur Respir J 2014: 44(4): 985-993.

13. Schupp JC, Vukmirovic M, Kaminski N, Prasse A. Transcriptome profiles in sarcoidosis and their potential role in disease prediction. Curr Opin Pulm Med 2017: 23(5): 487-492.

14. Moller DR, Koth LL, Maier LA, Morris A, Drake W, Rossman M, Leader JK, Collman RG, Hamzeh N, Sweiss NJ, Zhang Y, O'Neal S, Senior RM, Becich M, Hochheiser HS, Kaminski N, Wisniewski SR, Gibson KF, Group GSS. Rationale and Design of the Genomic Research in Alpha-1 Antitrypsin Deficiency and Sarcoidosis (GRADS) Study. Sarcoidosis Protocol. Ann Am Thorac Soc 2015: 12(10): 1561-1571. 
medRxiv preprint doi: https://doi.org/10.1101/2020.07.24.20161448; this version posted July 27, 2020. The copyright holder for this preprint

(which was not certified by peer review) is the author/funder, who has granted medRxiv a license to display the preprint in perpetuity.

It is made available under a CC-BY-NC-ND 4.0 International license .

15. Newman LS, Rose CS, Bresnitz EA, Rossman MD, Barnard J, Frederick M, Terrin ML, Weinberger SE, Moller DR, McLennan G, Hunninghake G, DePalo L, Baughman RP, lannuzzi MC, Judson MA, Knatterud GL, Thompson BW, Teirstein AS, Yeager H, Jr., Johns CJ, Rabin DL, Rybicki BA, Cherniack R. A case control etiologic study of sarcoidosis: environmental and occupational risk factors. Am J Respir Crit Care Med 2004: 170(12): 1324-1330.

16. Kim S, Herazo-Maya JD, Kang DD, Juan-Guardela BM, Tedrow J, Martinez FJ, Sciurba FC, Tseng GC, Kaminski N. Integrative phenotyping framework (iPF): integrative clustering of multiple omics data identifies novel lung disease subphenotypes. BMC Genomics 2015: 16: 924.

17. Langfelder P, Horvath S. WGCNA: an R package for weighted correlation network analysis. BMC Bioinformatics 2008: 9: 559.

18. Bauer Y, Tedrow J, de Bernard S, Birker-Robaczewska M, Gibson KF, Guardela BJ, Hess P, Klenk A, Lindell KO, Poirey S, Renault B, Rey M, Weber E, Nayler O, Kaminski N. A novel genomic signature with translational significance for human idiopathic pulmonary fibrosis. American journal of respiratory cell and molecular biology 2015: 52(2): 217-231.

19. Poliska S, Csanky E, Szanto A, Szatmari I, Mesko B, Szeles L, Dezso B, Scholtz B, Podani J, Kilty I, Takacs L, Nagy L. Chronic obstructive pulmonary disease-specific gene expression signatures of alveolar macrophages as well as peripheral blood monocytes overlap and correlate with lung function. Respiration 2011: 81(6): 499-510. 
medRxiv preprint doi: https://doi.org/10.1101/2020.07.24.20161448; this version posted July 27, 2020. The copyright holder for this preprint

(which was not certified by peer review) is the author/funder, who has granted medRxiv a license to display the preprint in perpetuity.

It is made available under a CC-BY-NC-ND 4.0 International license .

20. Mayr R, Janecke AR, Schranz M, Griffiths WJH, Vogel W, Pietrangelo A, Zoller

H. Ferroportin disease: a systematic meta-analysis of clinical and molecular findings. $J$ Hepatol 2010: 53(5): 941-949.

21. M. Yap L, Lottaz D, Ahmad T, Schieber L, Van Heel D, McGovern D, Negoro K, Sterchi E, Sanderson I, Welsh K, Jewell D. Polymorphisms in the MEP1A Gene, 2006.

22. Bucova M, Suchankova M, Tibenska E, Majer I, Novosadova H, Urban S.

Diagnostic value of TREM-1 and TREM-2 expression in bronchoalveolar lavage fluid in sarcoidosis and other lung diseases. Bratis/ Lek Listy 2015: 116(12): 707-713.

23. Bergantini L, Bianchi F, Cameli P, Mazzei MA, Fui A, Sestini P, Rottoli P, Bargagli E. Prognostic Biomarkers of Sarcoidosis: A Comparative Study of Serum Chitotriosidase, ACE, Lysozyme, and KL-6. Dis Markers 2019: 2019: 8565423.

24. Su R, Li MM, Bhakta NR, Solberg OD, Darnell EPB, Ramstein J, Garudadri S, Ho M, Woodruff PG, Koth LL. Longitudinal analysis of sarcoidosis blood transcriptomic signatures and disease outcomes. European Respiratory Journal 2014: 44(4): 985-993.

25. Pignatti P, Brunetti G, Moretto D, Yacoub MR, Fiori M, Balbi B, Balestrino A, Cervio G, Nava S, Moscato G. Role of the chemokine receptors CXCR3 and CCR4 in human pulmonary fibrosis. Am J Respir Crit Care Med 2006: 173(3): 310-317.

26. Burgstaller G, Oehrle B, Gerckens M, White ES, Schiller HB, Eickelberg O. The instructive extracellular matrix of the lung: basic composition and alterations in chronic lung disease. Eur Respir J 2017: 50(1).

27. Yang L, Seki E. Toll-like receptors in liver fibrosis: cellular crosstalk and mechanisms. Front Physiol 2012: 3: 138-138. 
medRxiv preprint doi: https://doi.org/10.1101/2020.07.24.20161448; this version posted July 27, 2020. The copyright holder for this preprint

(which was not certified by peer review) is the author/funder, who has granted medRxiv a license to display the preprint in perpetuity.

It is made available under a CC-BY-NC-ND 4.0 International license .

28. Königshoff M, Balsara N, Pfaff E-M, Kramer M, Chrobak I, Seeger W, Eickelberg O. Functional Wnt signaling is increased in idiopathic pulmonary fibrosis. PloS one 2008: 3(5): e2142-e2142.

29. Sunaga $H$, Matsui $H$, Ueno M, Maeno T, Iso T, Syamsunarno MRAA, Anjo S, Matsuzaka T, Shimano H, Yokoyama T, Kurabayashi M. Deranged fatty acid composition causes pulmonary fibrosis in Elovl6-deficient mice. Nature Communications 2013: 4: 2563 .

30. Lal S, Wong ZW, Jada SR, Xiang X, Chen Shu X, Ang PC, Figg WD, Lee EJ, Chowbay B. Novel SLC22A16 polymorphisms and influence on doxorubicin pharmacokinetics in Asian breast cancer patients. Pharmacogenomics 2007: 8(6): 567575.

31. Burke RR, Stone $\mathrm{CH}$, Havstad S, Rybicki BA. Racial differences in sarcoidosis granuloma density. Lung 2009: 187(1): 1-7.

32. Meyer KC, Raghu G. Bronchoalveolar lavage for the evaluation of interstitial lung disease: is it clinically useful? European Respiratory Journal 2011: 38(4): 761-769.

33. Gimferrer I, Farnos M, Calvo M, Mittelbrunn M, Enrich C, Sanchez-Madrid F, Vives J, Lozano F. The accessory molecules CD5 and CD6 associate on the membrane of lymphoid T cells. J Biol Chem 2003: 278(10): 8564-8571.

34. Brown MH, Cantrell DA, Brattsand G, Crumpton MJ, Gullberg M. The CD2 antigen associates with the T-cell antigen receptor CD3 antigen complex on the surface of human T lymphocytes. Nature 1989: 339(6225): 551-553.

35. Georgiev H, Ravens I, Papadogianni G, Bernhardt G. Coming of Age: CD96 Emerges as Modulator of Immune Responses. Front Immunol 2018: 9: 1072-1072. 
36. Rudemiller N, Lund H, Jacob HJ, Geurts AM, Mattson DL. CD247 modulates blood pressure by altering T-lymphocyte infiltration in the kidney. Hypertension 2014: 63(3): 559-564.

37. Cuenca M, Sintes J, Lanyi A, Engel P. CD84 cell surface signaling molecule: An emerging biomarker and target for cancer and autoimmune disorders. Clin Immunol 2019: 204: 43-49.

38. Ebert LM, McColl SR. Up-regulation of CCR5 and CCR6 on distinct subpopulations of antigen-activated CD4+ T lymphocytes. J Immunol 2002: 168(1): 6572.

39. Facco M, Baesso I, Miorin M, Bortoli M, Cabrelle A, Boscaro E, Gurrieri C, Trentin L, Zambello R, Calabrese F, Cassatella MA, Semenzato G, Agostini C. Expression and role of CCR6/CCL20 chemokine axis in pulmonary sarcoidosis. $J$ Leukoc Biol 2007: 82(4): 946-955.

40. Spagnolo P, Renzoni EA, Wells AU, Copley SJ, Desai SR, Sato H, Grutters JC, Abdallah A, Taegtmeyer A, du Bois RM, Welsh KI. C-C chemokine receptor 5 gene variants in relation to lung disease in sarcoidosis. Am J Respir Crit Care Med 2005: 172(6): 721-728.

41. Cuenca M, Punet-Ortiz J, Ruart M, Terhorst C, Engel P. Ly9 (SLAMF3) receptor differentially regulates iNKT cell development and activation in mice. Eur J Immunol 2018: 48(1): 99-105.

42. Culver DA, Baughman RP. It's time to evolve from Scadding: phenotyping sarcoidosis. Eur Respir J 2018: 51(1). 
43. Schupp JC, Freitag-Wolf S, Bargagli E, Mihailovic-Vucinic V, Rottoli P, Grubanovic A, Muller A, Jochens A, Tittmann L, Schnerch J, Olivieri C, Fischer A, Jovanovic D, Filipovic S, Videnovic-Ivanovic J, Bresser P, Jonkers R, O'Reilly K, Ho LP, Gaede KI, Zabel P, Dubaniewicz A, Marshall B, Kieszko R, Milanowski J, Gunther A, Weihrich A, Petrek M, Kolek V, Keane MP, O'Beirne S, Donnelly S, Haraldsdottir SO, Jorundsdottir KB, Costabel U, Bonella F, Wallaert B, Grah C, Peros-Golubicic T, Luisetti M, Kadija Z, Pabst S, Grohe C, Strausz J, Vasakova M, Sterclova M, Millar A, Homolka J, Slovakova A, Kendrick Y, Crawshaw A, Wuyts W, Spencer L, Pfeifer M, Valeyre D, Poletti V, Wirtz H, Prasse A, Schreiber S, Krawczak M, Muller-Quernheim J. Phenotypes of organ involvement in sarcoidosis. Eur Respir J 2018: 51(1).

44. Ramos-Casals M, Kostov B, Brito-Zeron P, Siso-Almirall A, Baughman RP. How the Frequency and Phenotype of Sarcoidosis is Driven by Environmental Determinants. Lung 2019.

45. Broos CE, Hendriks RW, Kool M. T-cell immunology in sarcoidosis: Disruption of a delicate balance between helper and regulatory T-cells. Curr Opin Pulm Med 2016: 22(5): 476-483.

46. Chen ES. Innate immunity in sarcoidosis pathobiology. Curr Opin Pulm Med 2016: 22(5): 469-475.

47. Schnerch J, Prasse A, Vlachakis D, Schuchardt KL, Pechkovsky DV, Goldmann T, Gaede KI, Muller-Quernheim J, Zissel G. Functional Toll-Like Receptor 9 Expression and CXCR3 Ligand Release in Pulmonary Sarcoidosis. Am J Respir Cell Mol Biol 2016: 55(5): 749-757. 
medRxiv preprint doi: https://doi.org/10.1101/2020.07.24.20161448; this version posted July 27, 2020. The copyright holder for this preprint

(which was not certified by peer review) is the author/funder, who has granted medRxiv a license to display the preprint in perpetuity.

It is made available under a CC-BY-NC-ND 4.0 International license .

48. Bonham CA, Strek ME, Patterson KC. From granuloma to fibrosis: sarcoidosis associated pulmonary fibrosis. Curr Opin Pulm Med 2016: 22(5): 484-491.

49. Linke M, Pham HT, Katholnig K, Schnoller T, Miller A, Demel F, Schutz B, Rosner M, Kovacic B, Sukhbaatar N, Niederreiter B, Bluml S, Kuess P, SexI V, Muller M, Mikula M, Weckwerth W, Haschemi A, Susani M, Hengstschlager M, Gambello MJ, Weichhart T. Chronic signaling via the metabolic checkpoint kinase mTORC1 induces macrophage granuloma formation and marks sarcoidosis progression. Nat Immunol 2017: 18(3): 293-302.

50. Salazar A, Pinto X, Mana J. Serum amyloid A and high-density lipoprotein cholesterol: serum markers of inflammation in sarcoidosis and other systemic disorders. Eur J Clin Invest 2001: 31(12): 1070-1077.

51. Facco M, Cabrelle A, Teramo A, Olivieri V, Gnoato M, Teolato S, Ave E, Gattazzo C, Fadini GP, Calabrese F, Semenzato G, Agostini C. Sarcoidosis is a Th1/Th17 multisystem disorder. Thorax 2011: 66(2): 144-150.

52. Ostadkarampour M, Eklund A, Moller D, Glader P, Olgart Hoglund C, Linden A, Grunewald J, Wahlstrom J. Higher levels of interleukin IL-17 and antigen-specific IL-17 responses in pulmonary sarcoidosis patients with Lofgren's syndrome. Clin Exp Immunol 2014: 178(2): 342-352.

53. Prasse A, Katic C, Germann M, Buchwald A, Zissel G, Muller-Quernheim J. Phenotyping sarcoidosis from a pulmonary perspective. Am J Respir Crit Care Med 2008: 177(3): 330-336.

54. Baughman RP, Nagai S, Balter M, Costabel U, Drent M, du Bois R, Grutters JC, Judson MA, Lambiri I, Lower EE, Muller-Quernheim J, Prasse A, Rizzato G, Rottoli P, 
Spagnolo P, Teirstein A. Defining the clinical outcome status (COS) in sarcoidosis: results of WASOG Task Force. Sarcoidosis Vasc Diffuse Lung Dis 2011: 28(1): 56-64. 55. Baughman RP, Lower EE. Treatment of Sarcoidosis. Clin Rev Allergy Immunol 2015: 49(1): 79-92.

56. Rybicki BA, Sinha R, lyengar S, Gray-McGuire C, Elston RC, lannuzzi MC, Consortium SS. Genetic linkage analysis of sarcoidosis phenotypes: the sarcoidosis genetic analysis (SAGA) study. Genes Immun 2007: 8(5): 379-386. 
Table 1a. Demographic and clinical characteristics of the GRADS cohort categorized by the phenotypic groups.

\begin{tabular}{|c|c|c|c|c|c|c|c|c|}
\hline PHENOTYPE GROUPS & 1. MULTIORGAN & $\begin{array}{l}\text { 2. NON ACUTE } \\
\text { STAGE I } \\
\text { UNTREATED }\end{array}$ & $\begin{array}{l}\text { 3. STAGE II-III } \\
\text { TREATED }\end{array}$ & $\begin{array}{l}\text { 4. STAGE II-III } \\
\text { UNTREATED }\end{array}$ & $\begin{array}{l}\text { 5. STAGE IV } \\
\text { TREATED }\end{array}$ & $\begin{array}{l}\text { 6. STAGE IV } \\
\text { UNTREATED }\end{array}$ & $\begin{array}{l}\text { 7. ACUTE } \\
\text { UNTREATED }\end{array}$ & $\begin{array}{c}8 . \\
\text { REMITTING } \\
\text { UNTREATED }\end{array}$ \\
\hline TOTAL, $\mathbf{n}$ & 23 & 25 & 34 & 42 & 19 & 12 & 14 & 40 \\
\hline \multicolumn{9}{|l|}{ SCADDING } \\
\hline Stage $0, n(\%)$ & $4(17.4 \%)$ & $0(0.0 \%)$ & $1(2.9 \%)$ & $0(0.0 \%)$ & $0(0.0 \%)$ & $0(0.0 \%)$ & $2(14.3 \%)$ & $14(35.0 \%)$ \\
\hline Stage $1, \mathrm{n}(\%)$ & $7(30.4 \%)$ & $24(96.0 \%)$ & $0(0.0 \%)$ & $0(0.0 \%)$ & $0(0.0 \%)$ & $0(0.0 \%)$ & $9(64.3 \%)$ & $14(35.0 \%)$ \\
\hline Stage $2, \mathrm{n}(\%)$ & $6(26.1 \%)$ & $0(0.0 \%)$ & $23(67.7 \%)$ & $34(81.0 \%)$ & $0(0.0 \%)$ & $0(0.0 \%)$ & $3(21.4 \%)$ & $7(17.5 \%)$ \\
\hline Stage 3, n (\%) & $4(17.4 \%)$ & $0(0.0 \%)$ & $10(29.4 \%)$ & $8(19.0 \%)$ & $0(0.0 \%)$ & $0(0.0 \%)$ & $0(0.0 \%)$ & $5(12.5 \%)$ \\
\hline Stage $4, n(\%)$ & $2(8.7 \%)$ & $0(0.0 \%)$ & $0(0.0 \%)$ & $0(0.0 \%)$ & $19(100 \%)$ & $12(100 \%)$ & $0(0.0 \%)$ & $0(0.0 \%)$ \\
\hline$N A, n(\%)$ & $0(0.0 \%)$ & $1(4.0 \%)$ & $0(0.0 \%)$ & $0(0.0 \%)$ & $0(0.0 \%)$ & $0(0.0 \%)$ & $0(0.0 \%)$ & $0(0.0 \%)$ \\
\hline FEMALE GENDER, n (\%) & $12(52.2 \%)$ & $18(72.0 \%)$ & $18(52.9 \%)$ & $19(45.2 \%)$ & $9(47.4 \%)$ & $6(50.0 \%)$ & $9(64.3 \%)$ & $21(52.5 \%)$ \\
\hline AGE, years (mean $\pm S D$ ) & $54.6 \pm 10.8$ & $46.2 \pm 10.9$ & $54.3 \pm 9.9$ & $50.2 \pm 9.3$ & $52.9 \pm 8.0$ & $49.8 \pm 10.4$ & $51.4 \pm 12.2$ & $52.2 \pm 9.8$ \\
\hline AGE, range, years & $30.9-69.6$ & $27.3-64.9$ & $34.8-74.9$ & $26.0-68.2$ & $39.3-69.5$ & $32.7-63.6$ & $30.8-66.9$ & $26.3-71.5$ \\
\hline \multicolumn{9}{|l|}{ RACE } \\
\hline Caucasian/White, $\mathrm{n}$ & $15(65.2 \%)$ & $21(84.0 \%)$ & $22(64.7 \%)$ & $31(73.8 \%)$ & $13(68.4 \%)$ & $9(75.0 \%)$ & $9(64.3 \%)$ & $33(82.5 \%)$ \\
\hline African American/Black, $\mathrm{n}$ & $8(34.8 \%)$ & $4(16.0 \%)$ & $8(23.5 \%)$ & $10(23.8 \%)$ & $6(31.6 \%)$ & $3(25.0 \%)$ & $4(28.6 \%)$ & $6(15.0 \%)$ \\
\hline Other, $n$ & $0(0.0 \%)$ & $0(0.0 \%)$ & $4(11.8 \%)$ & $1(2.4 \%)$ & $0(0.0 \%)$ & $0(0.0 \%)$ & $1(7.1 \%)$ & $1(2.5 \%)$ \\
\hline FEV1 (L), mean \pm SD & $2.6 \pm 1.3$ & $2.8 \pm 0.8$ & $2.3 \pm 0.8$ & $2.9 \pm 0.8$ & $2.08 \pm 0.8$ & $2.4 \pm 1.9$ & $3.0 \pm 0.6$ & $3.1 \pm 0.9$ \\
\hline FEV1\% PRED, mean \pm SD & $90.0 \pm 13.4$ & $84.5 \pm 30.9$ & $78.6 \pm 20.2$ & $84.24 \pm 26.2$ & $69.5 \pm 21.3$ & $84.2 \pm 25.9$ & $86.1 \pm 39.4$ & $96.2 \pm 21.4$ \\
\hline FVC (L), mean \pm SD & $3.4 \pm 1.6$ & $3.7 \pm 1.0$ & $3.2 \pm 1.1$ & $3.9 \pm 1.0$ & $3.1 \pm 0.9$ & $3.5 \pm 2.4$ & $3.7 \pm 0.8$ & $4.0 \pm 1.2$ \\
\hline FVC $\%$ PRED, mean \pm SD & $89.2 \pm 11.4$ & $84.8 \pm 29.4$ & $82.5 \pm 18.8$ & $85.5 \pm 24.4$ & $78.2 \pm 16.2$ & $91.3 \pm 23.9$ & $83.1 \pm 38.0$ & $93.9 \pm 20.4$ \\
\hline $\begin{array}{l}\mathrm{DLCO}(\mathrm{ml} / \mathrm{min} / \mathrm{mmHg}) \\
\text { mean } \pm \mathrm{SD}\end{array}$ & $23.5 \pm 8.6$ & $21.8 \pm 10.6$ & $20.1 \pm 9.5$ & $23.8 \pm 8.8$ & $21.7 \pm 8.9$ & $20.7 \pm 11.8$ & $19.5 \pm 11.0$ & $27.3 \pm 9.9$ \\
\hline DLCO $\%$, mean $\pm S D$ & $86.1 \pm 24.1$ & $85.8 \pm 26.4$ & $69.5 \pm 28.1$ & $81.0 \pm 24.5$ & $72.4 \pm 18.1$ & $67.3 \pm 28.1$ & $74.1 \pm 37.3$ & $90.7 \pm 23.9$ \\
\hline
\end{tabular}

Definition of abbreviations: PFT\% PRED: pre-bronchodilator PFT in predicted percentage. 
Table 1b. Patient characteristics of the GRADS and Freiburg cohort for the 12 overlapping clinical features.

\begin{tabular}{|c|c|c|c|}
\hline & GRADS & Freiburg & $P$ value \\
\hline TOTAL, $\mathbf{n}$ & 209 & 50 & \\
\hline SCADDING & & & 0.02 \\
\hline Stage $0, \mathrm{n}(\%)$ & $21(10.1 \%)$ & $0(0.0 \%)$ & \\
\hline Stage $1, \mathrm{n}(\%)$ & $54(25.8 \%)$ & $5(10.0 \%)$ & \\
\hline Stage $2, \mathrm{n}(\%)$ & $73(34.9 \%)$ & $28(56.0 \%)$ & \\
\hline Stage $3, \mathrm{n}(\%)$ & $27(12.9 \%)$ & $11(22.0 \%)$ & \\
\hline Stage $4, \mathrm{n}(\%)$ & $33(15.8 \%)$ & $6(12.0 \%)$ & \\
\hline $\mathrm{NA}, \mathrm{n}(\%)$ & $1(0.5 \%)$ & $0(0.0 \%)$ & \\
\hline FEMALE GENDER, n (\%) & $112(53.6 \%)$ & $18(36.0 \%)$ & 0.04 \\
\hline AGE, years (mean $\pm S D$ ) & $51.6 \pm 10.2$ & $46.3 \pm 13.2$ & $2.9 \times 10^{-3}$ \\
\hline AGE, range & $26.0-74.9$ & $21.0-81.0$ & \\
\hline FEV1 (L), mean \pm SD & $2.7 \pm 1.0$ & $2.6 \pm 0.9$ & 0.497 \\
\hline FEV1\% PRED, mean \pm SD & $85.1 \pm 25.3$ & $72.9 \pm 20.9$ & $2.0 \times 10^{-4}$ \\
\hline FVC (L), mean \pm SD & $3.6 \pm 1.2$ & $3.5 \pm 1.1$ & 0.45 \\
\hline FVC $\%$ PRED, mean \pm SD & $86.5 \pm 23.0$ & $81.4 \pm 20.3$ & 0.05 \\
\hline FEV1/FVC ratio, mean \pm SD & $0.8 \pm 0.1$ & $0.8 \pm 0.1$ & 0.92 \\
\hline MACROPHAGE $\%$, mean \pm SD & $73.2 \pm 32.0$ & $54.2 \pm 21.2$ & $2.6 \times 10^{-9}$ \\
\hline LYMPHOCYTE, mean $₫ \pm S D$ & $10.5 \pm 11.5$ & $41.5 \pm 21.6$ & $1.4 \times 10^{-19}$ \\
\hline NEUTROPHIL, mean $\urcorner \pm S D$ & $1.2 \pm 2.5$ & $2.8 \pm 4.4$ & $9.0 \times 10^{-5}$ \\
\hline EOSINOPHIL, mean $\urcorner \pm S D$ & $0.21 \pm 0.95$ & $1.08 \pm 1.29$ & $6.1 \times 10^{-13}$ \\
\hline
\end{tabular}


medRxiv preprint doi: https://doi.org/10.1101/2020.07.24.20161448; this version posted July 27 , 2020. The copyright holder for this preprint (which was not certified by peer review) is the author/funder, who has granted medRxiv a license to display the preprint in perpetuity.

It is made available under a CC-BY-NC-ND 4.0 International license.

Table 2. Association between chosen molecular endotypes and the 12 overlapping clinical traits in

GRADS and Freiburg cohorts for validation. Each entry is a $p$ value for the difference of the given clinical trait between the two extreme clusters of patients identified using the the corresponding gene module in the corresponding cohort.

\begin{tabular}{|c|c|c|c|c|c|c|c|c|c|c|}
\hline & \multicolumn{2}{|c|}{$\begin{array}{l}\text { Module } 47 \\
\text { Gender module }\end{array}$} & \multicolumn{2}{|c|}{$\begin{array}{c}\text { Module } 4 \\
\text { Hilar } \\
\text { Lymphadenopathy } \\
\text { and Acute } \\
\text { Lymphocytic } \\
\text { Inflammation }\end{array}$} & \multicolumn{2}{|c|}{$\begin{array}{c}\text { Module } 33 \\
\text { Multiorgan } \\
\text { involvement with } \\
\text { increased immune } \\
\text { response }\end{array}$} & \multicolumn{2}{|c|}{$\begin{array}{l}\text { Module } 18 \\
\text { Chronic } \\
\text { sarcoidosis }\end{array}$} & \multicolumn{2}{|c|}{$\begin{array}{c}\text { Module } 1 \\
\text { Extraocular organ } \\
\text { involvement and } \\
\text { PI3K activation }\end{array}$} \\
\hline & $\begin{array}{l}\text { GRADS } \\
\text { (A vs B) } \\
P \text { value }\end{array}$ & $\begin{array}{l}\text { Freiburg } \\
\text { (A vs } B) \\
P \text { value }\end{array}$ & $\begin{array}{l}\text { GRADS } \\
\text { (A vs } C \text { ) } \\
\text { P value }\end{array}$ & $\begin{array}{l}\text { Freiburg } \\
\text { (A vs C) } \\
P \text { value }\end{array}$ & $\begin{array}{l}\text { GRADS } \\
\text { (B vs C) } \\
P \text { value }\end{array}$ & $\begin{array}{l}\text { Freiburg } \\
\text { (B vs C) } \\
P \text { value }\end{array}$ & $\begin{array}{l}\text { GRADS } \\
\text { (B vs C) } \\
P \text { value }\end{array}$ & $\begin{array}{l}\text { Freiburg } \\
\text { (A vs D) } \\
P \text { value }\end{array}$ & $\begin{array}{l}\text { GRADS } \\
\text { (A vs } B \text { ) } \\
P \text { value }\end{array}$ & $\begin{array}{l}\text { Freiburg } \\
\text { (B vs C) } \\
P \text { value }\end{array}$ \\
\hline SCADDING & 0.02 & 0.11 & 0.01 & 0.34 & 0.53 & 0.06 & 0.24 & 0.15 & 0.44 & 0.79 \\
\hline AGE & 0.80 & 0.59 & 0.07 & 0.66 & 0.91 & 0.28 & 0.66 & 0.78 & 0.45 & 0.29 \\
\hline GENDER & $<5 \times 10^{-4}$ & $2.1 \times 10^{-11}$ & 0.24 & $9 \times 10^{-3}$ & 0.43 & 0.29 & 0.64 & 0.08 & 0.86 & 1 \\
\hline MACROPHAGE & 0.75 & 0.05 & $7 \times 10^{-8}$ & $5 \times 10^{-3}$ & $2 \times 10^{-5}$ & $1 \times 10^{-3}$ & 0.04 & 0.01 & 0.53 & 0.33 \\
\hline LYMPHOCYTES & 0.53 & 0.05 & $9 \times 10^{-8}$ & $5 \times 10^{-3}$ & $2 \times 10^{-5}$ & $1 \times 10^{-3}$ & 0.03 & 0.01 & 0.35 & 0.44 \\
\hline NEUTROPHILS & 0.16 & 0.47 & 0.01 & 0.03 & 0.06 & $8 \times 10^{-3}$ & 0.16 & 0.05 & 0.46 & 0.004 \\
\hline EOSINOPHILS & 0.80 & 0.84 & $8 \times 10^{-5}$ & 0.39 & 0.03 & 0.38 & 0.85 & 0.14 & 0.11 & 0.40 \\
\hline FVC & $9 \times 10^{-15}$ & $3 \times 10^{-3}$ & 0.23 & 0.33 & 0.23 & 0.30 & 0.82 & 0.5 & 0.11 & 0.19 \\
\hline FEV1 & $2 \times 10^{-9}$ & $8 \times 10^{-3}$ & 0.62 & 0.30 & 0.47 & 0.39 & 0.80 & 0.38 & 0.06 & 0.22 \\
\hline FVC \% predicted & 0.98 & 0.14 & 0.79 & 0.64 & 0.97 & 0.08 & 0.82 & 0.33 & 0.01 & 0.19 \\
\hline FEV1\% predicted & 0.78 & 0.75 & 0.84 & 0.91 & 0.55 & 0.08 & 0.65 & 0.22 & 0.02 & 0.28 \\
\hline FEV1/FVC ratio & 0.36 & 0.03 & 0.26 & 0.71 & 0.25 & 0.72 & 0.29 & 1.00 & 0.90 & 0.87 \\
\hline
\end{tabular}


medRxiv preprint doi: https://doi.org/10.1101/2020.07.24.20161448; this version posted July 27, 2020. The copyright holder for this preprint (which was not certified by peer review) is the author/funder, who has granted medRxiv a license to display the preprint in perpetuity.

It is made available under a CC-BY-NC-ND 4.0 International license.

\section{Figure Legends}

Figure 1. Study workflow.

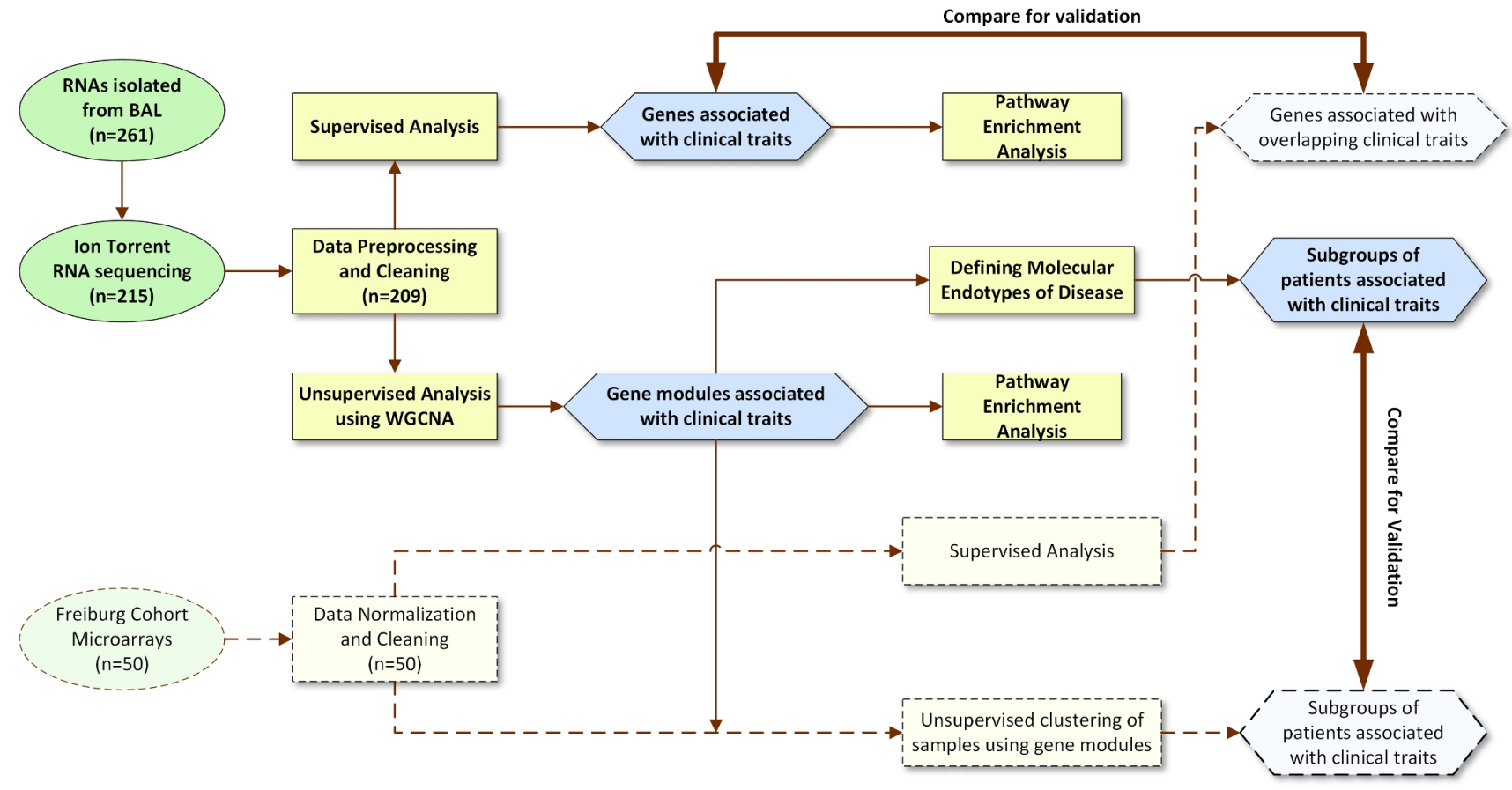


medRxiv preprint doi: https://doi.org/10.1101/2020.07.24.20161448; this version posted July 27, 2020. The copyright holder for this preprint (which was not certified by peer review) is the author/funder, who has granted medRxiv a license to display the preprint in perpetuity. It is made available under a CC-BY-NC-ND 4.0 International license .

Figure 2. Association of gene expression and clinical variables in supervised analyses. a) The number of genes shared between any two traits from a given set of clinical traits are shown in a squared matrix format with columns and rows both representing clinical traits. Entries colored in grey have zero overlap or FDR<0.05. The color of entries with non-grey color (white to yellow) describes the significance of overlap by Chi-suqare test. Each entry describes the number of genes in total in the first fow followed by rows describing the number of genes with a given direction of correlation in the parenteses (positive and negative correlations depicted by $(+)$ and $(-)$, respectively). b) The top 5 significant $($ FDR $<0.05)$ enriched pathways for genes associated with each clinical trait identified by GeneGo Metacore (Thomson Reuters) are shown as a Sankey plot. Genes significantly associated with each clinical trait are represented by bars on the left. These genes were further divided into positively and negatively correlated genes represented by bars in the middle colored in yellow and purple respectively. Each set of negatively or positively correlated genes was further connected to its signifticantly (FDR<0.05) enriched pathways (bars on the right). The lengths of all bars are proportional to the number of genes represented. Only the top 5 significant $($ FDR $<0.05)$ pathways with at least 3 genes correlated are shown. 
medRxiv preprint doi: https://doi.org/10.1101/2020.07.24.20161448; this version posted July 27, 2020. The copyright holder for this preprint (which was not certified by peer review) is the author/funder, who has granted medRxiv a license to display the preprint in perpetuity.

It is made available under a CC-BY-NC-ND 4.0 International license .

a)

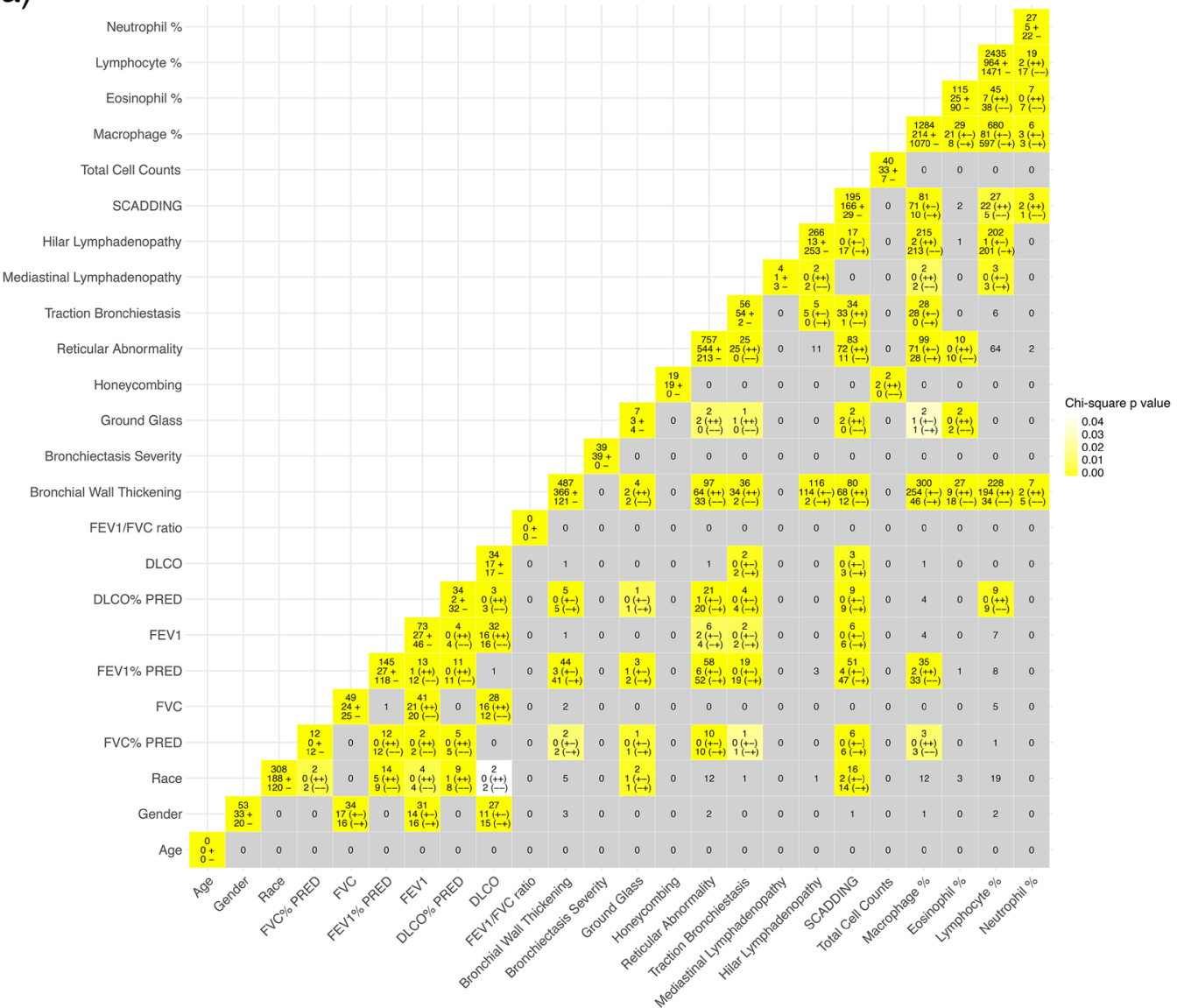

b)

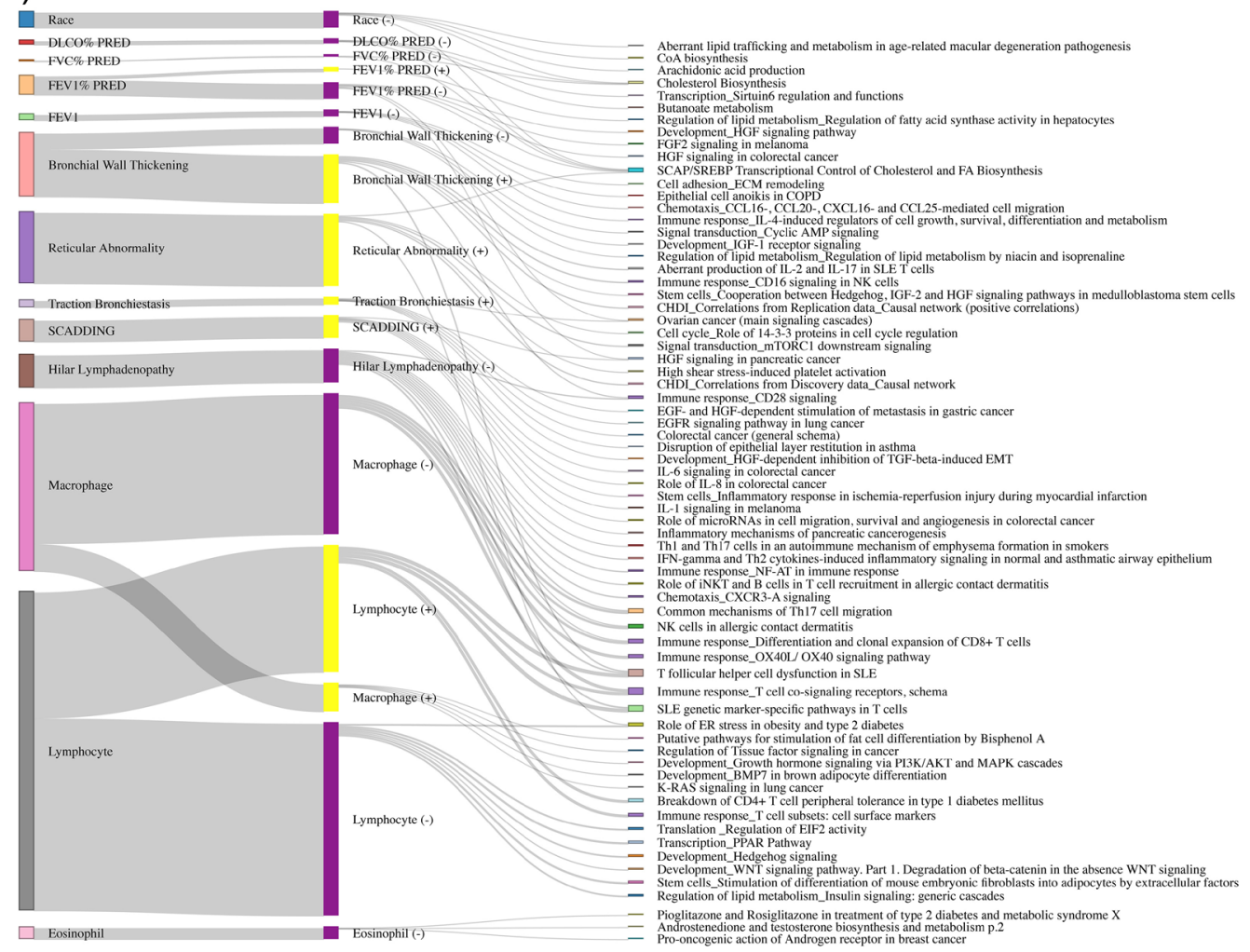


medRxiv preprint doi: https://doi.org/10.1101/2020.07.24.20161448; this version posted July 27, 2020. The copyright holder for this preprint (which was not certified by peer review) is the author/funder, who has granted medRxiv a license to display the preprint in perpetuity. It is made available under a CC-BY-NC-ND 4.0 International license.

Figure 3. Identification of novel endotypes of sarcoidosis using WGCNA. a) Heatmap showing the correlation between the 5 chosen gene modules and the clinical traits, including demographics, PFTs, CT imaging measures, BAL cell differentials, Scadding stage and treatment within stage III and IV. The correlation coefficient value and the corresponding $p$ value (in parentheses) are shown in each entry. b) Sankey plot visualizing the correlation between gene modules and clinical traits as well as the significant enriched pathways for each gene module. Only the top 5 significant $(F D R<0.05)$ pathways with at least 3 overlapping genes are shown. The positive and negative signs in parentheses represent positively and negatively correlated genes for continuous phenotypes, or increased and decreased for binary phenotypes, respectively. Details of the gene modules can be found at https://yalep2med.github.io/SARC BAL. 
medRxiv preprint doi: https://doi.org/10.1101/2020.07.24.20161448; this version posted July 27, 2020. The copyright holder for this preprint (which was not certified by peer review) is the author/funder, who has granted medRxiv a license to display the preprint in perpetuity.

It is made available under a CC-BY-NC-ND 4.0 International license .

a)

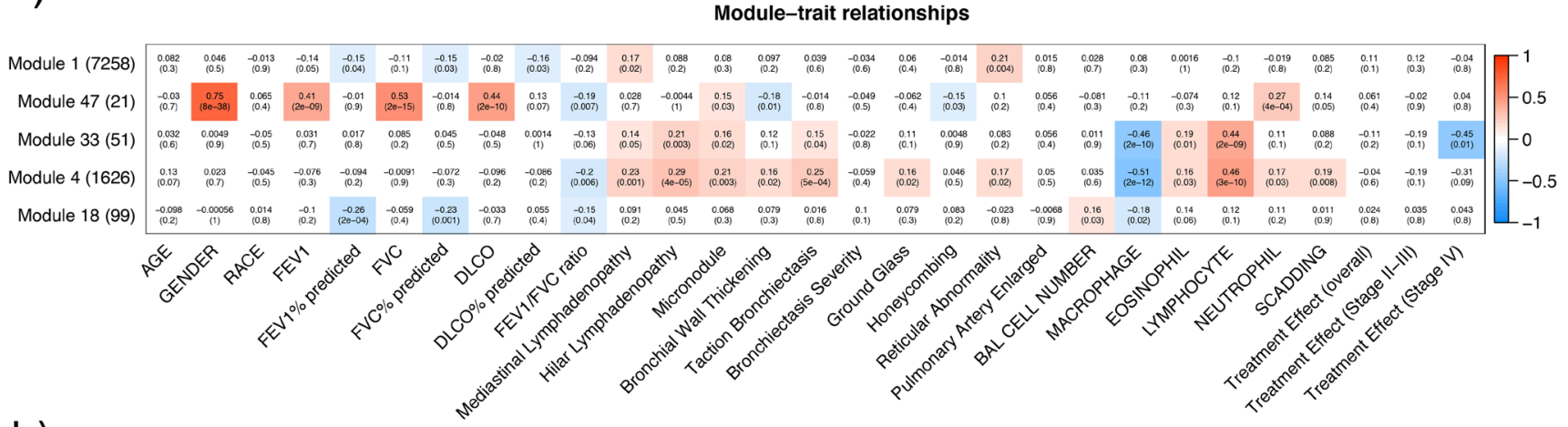

b)

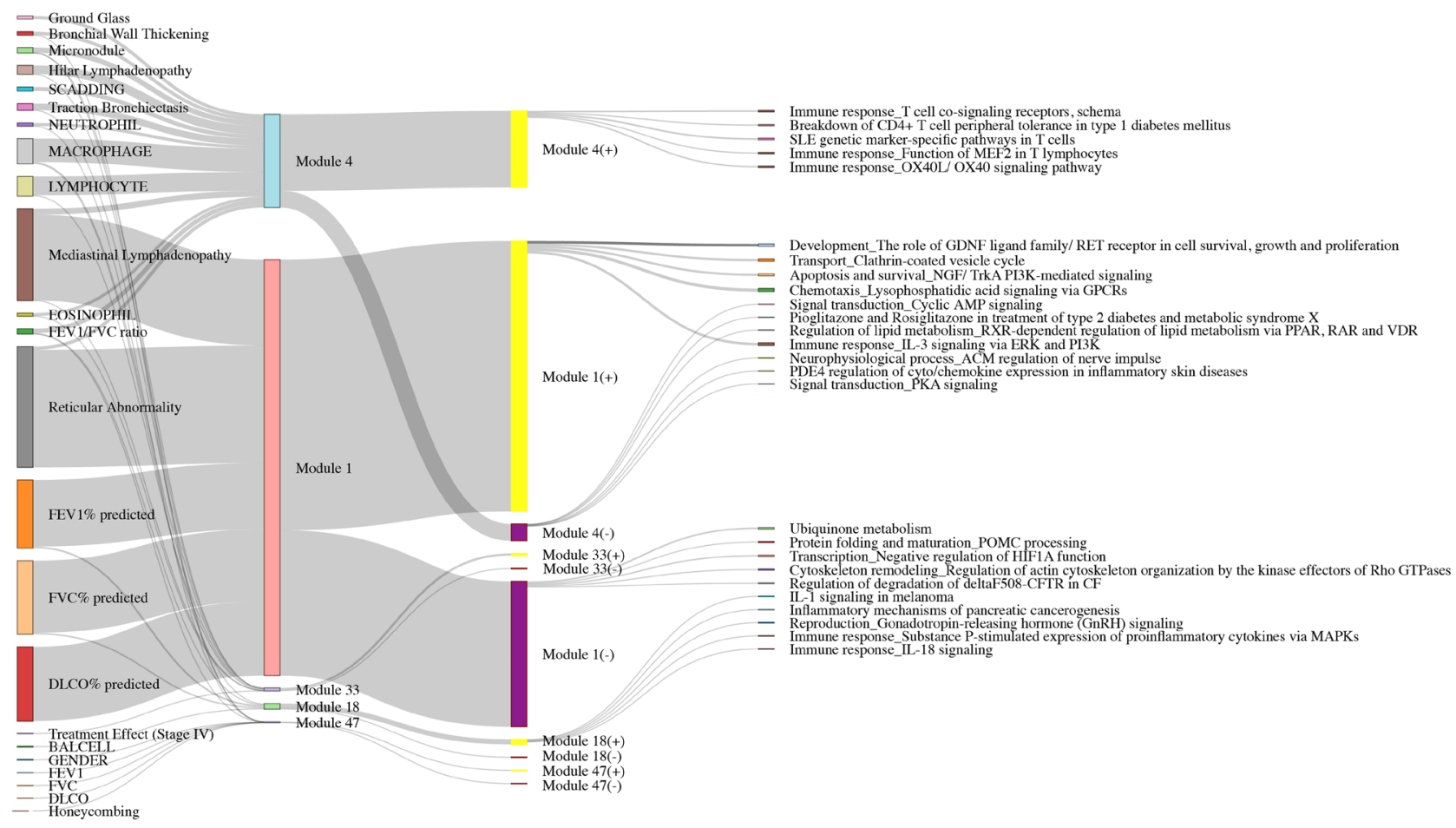


medRxiv preprint doi: https://doi.org/10.1101/2020.07.24.20161448; this version posted July 27, 2020. The copyright holder for this preprint (which was not certified by peer review) is the author/funder, who has granted medRxiv a license to display the preprint in perpetuity.

It is made available under a CC-BY-NC-ND 4.0 International license .

Figure 4. Heatmaps showing the expression pattern of the chosen gene modules and their corresponding K-means clustering results on the patients from GRADS cohort and Freiburg cohort. Panels a) to e) are heatmaps of the module $1,47,4,33$, and 18 , respectively. The patient clusters identified by K-means are labelled as cluster A, B, C and D on the top of the heatmaps. In each panel, the left heatmap is for GRADS cohort and the one on the right is for the Freiburg cohort. Genes in these two heatmaps are shown in the same order.

a)

Module 1

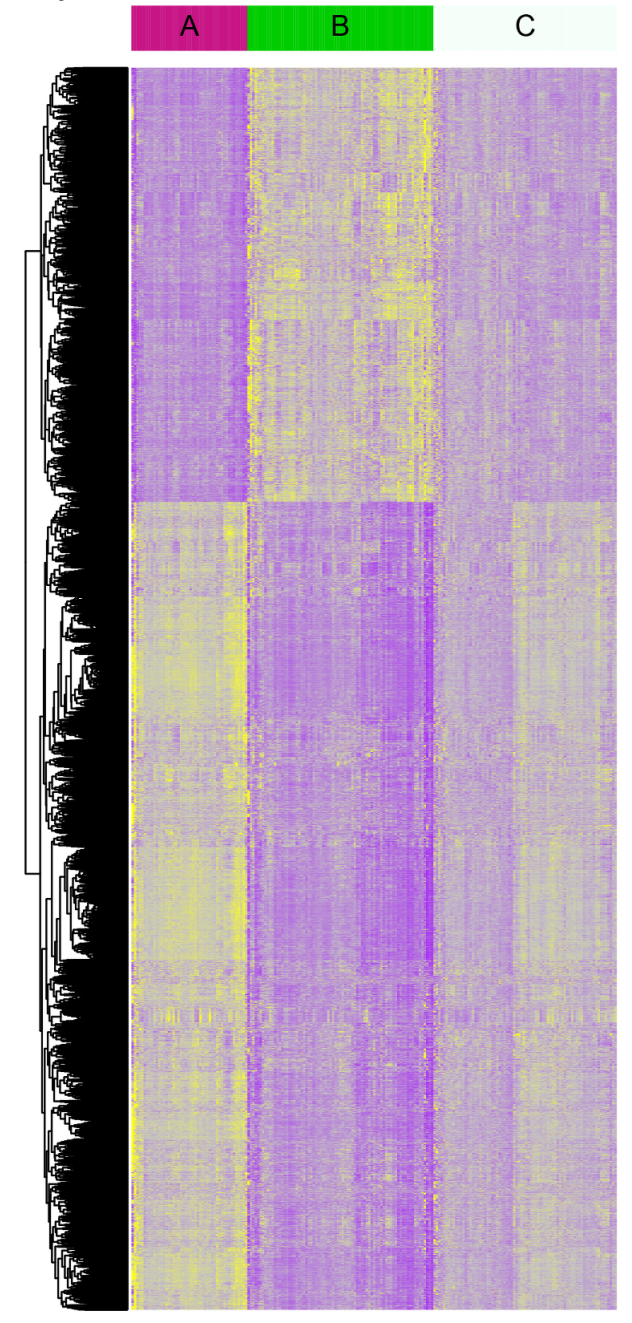

b)
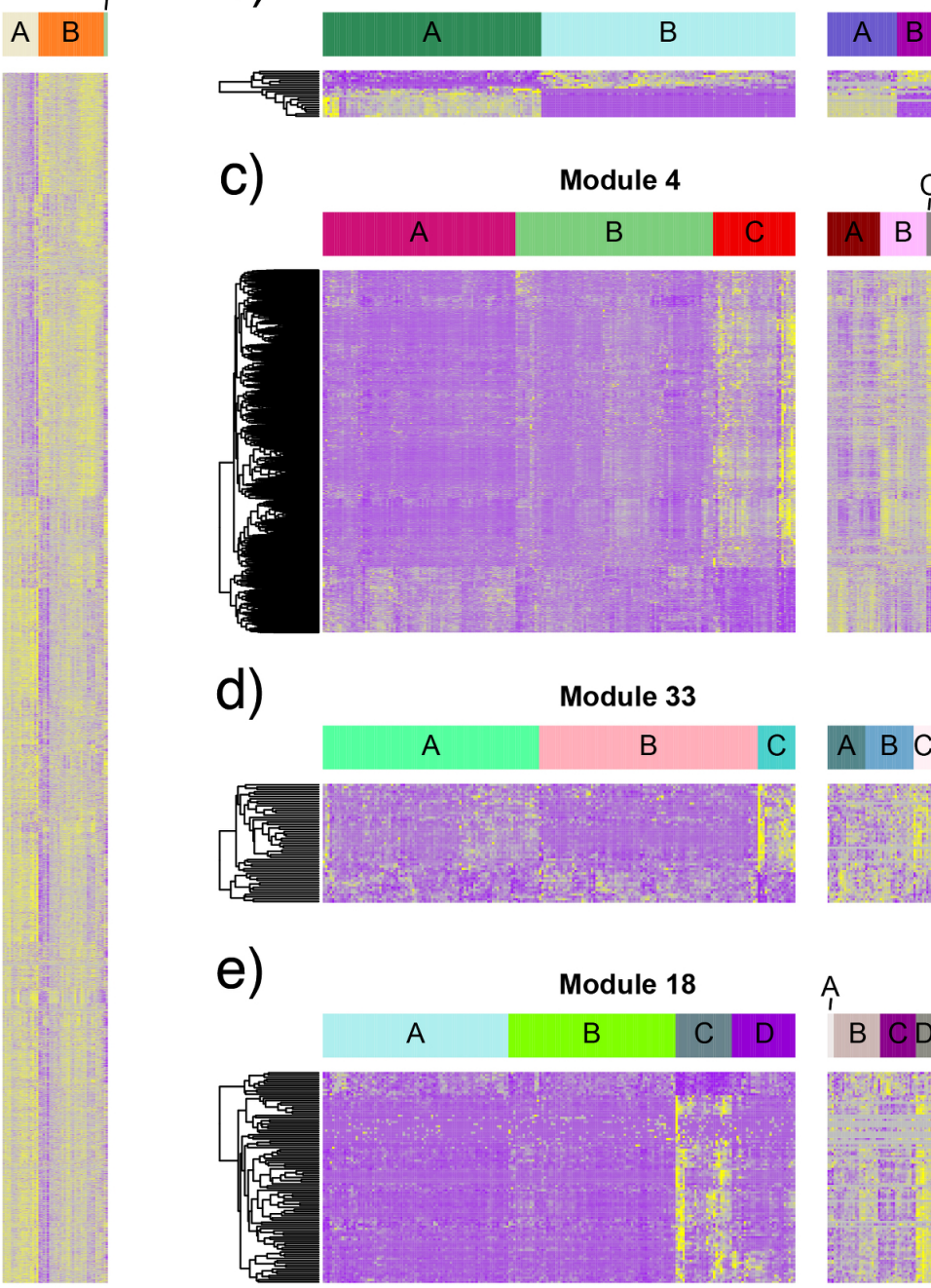

c)

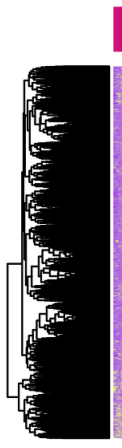

d)

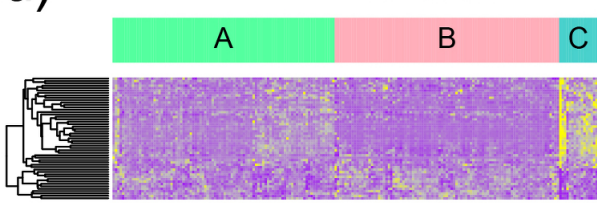

e)

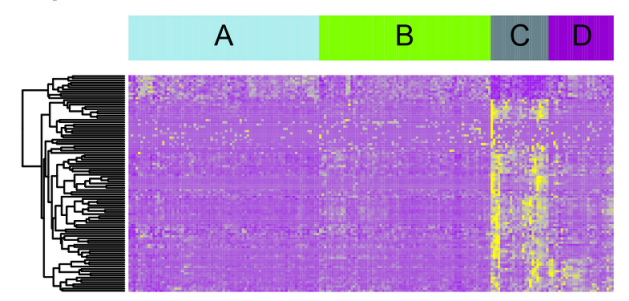

Module 18

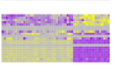

Module 4
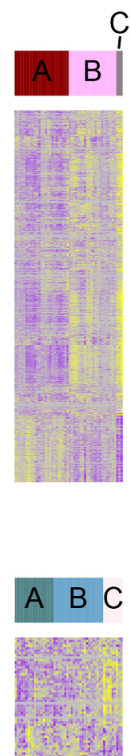

A
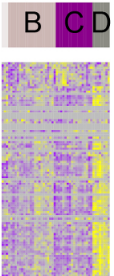